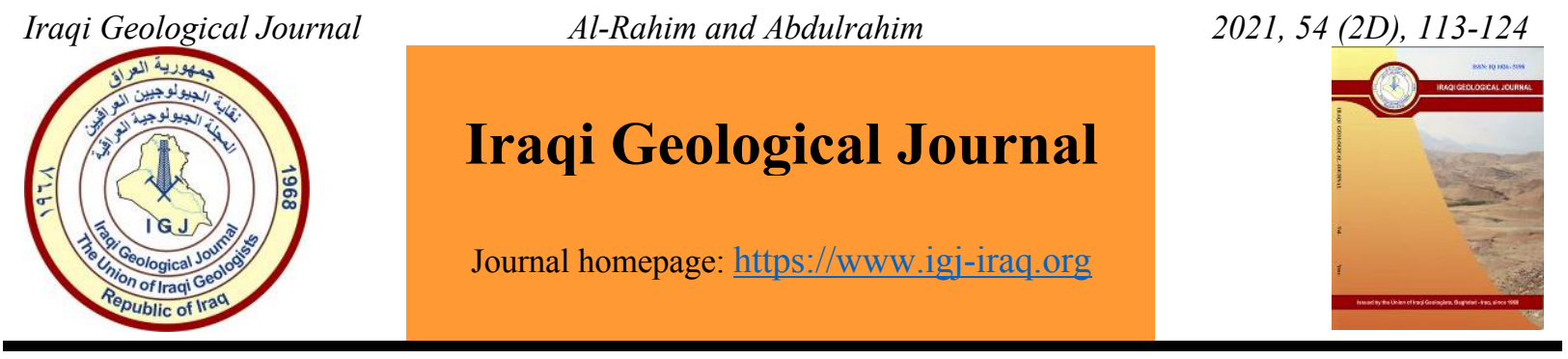

\title{
Gravity Study using Multi-2.5D Modeling and 3D Presentation for Al Ma'aniyah Depression, Southwest of Iraq
}

\author{
Ali M. Al-Rahim ${ }^{1}$ and Hussein Abdulrahim ${ }^{1, *}$ \\ 1 Department of Geology, College of Science, University of Baghdad, Baghdad, Iraq \\ * Correspondence: hussienalsaady662@yahoo.com
}

Received: 21 June 2021; Accepted: 27 July 2021; Published: 31 October 2021

\begin{abstract}
Tectonic depression area within and/or beside widespread basin is regarded as an important location for sub-basin sedimentary sequence of Iraq which may represent an excellent accumulation of bounded sediments. Al-Ma'aniyah depression, southwest Iraq is one of such type of sub-basin. Free-air gravity data show a NS extend of this depression inside Saudi Arabia. This work focuses on studying and multi-2.5D model creation for the depression in the Iraqi territory part using Bouguer gravity data and mapping its basement relief. Firstly, the exact boundary of the depression was outlined utilizing the Free-Air gravity data. Then, a precise selection of regional field for the study area was determined by using the power spectrum method, which accordingly defines the residual anomalies that could represent structural enclosures. Many positive anomalies were assigned and enhanced using vertical and total horizontal derivatives, where they were interpreted as basement related features. Subsequently, a 2.5D multi modeling and depth inversion for the Bouguer gravity data were accomplished by converting the gravity map to a stacked profiles depth map. A nineteen gravity profiles, which cover the study area, were modeled by assuming $2 \mathrm{D}$ intra-sedimentary bodies. These bodies were best presented by a $3 \mathrm{D}$ view that clarifies the nature of the subsurface modeled structures. The modeling shows an extra density at the northern part of the depression, in contrast, it suggests low density bodies at its southern part, the case that appears inconsistent with a previously performed magnetic interpretation. The inversion of gravity data shows that the basement depth at Al-Ma'aniyah depression ranges from 7.5 to $10 \mathrm{~km}$.
\end{abstract}

Key words: Al-Ma'aniyah depression; Forward and inverse modeling; Basement depth estimation

\section{Introduction}

Gravity methods play an important role in the recognition of sedimentary basins (Rao et al., 1994; Ali et al., 2014). Depicting the basement morphology below sedimentary basins using gravity data analysis is vital to predicting the hydrocarbon potential of a sedimentary basin and guiding exploration work. Depression of tectonic origin within and/or beside wide spread basin have special importance as Sub-Basin which may represent an excellent accumulation of bounded or restricted sedimentary sequence. The boundaries of this type of depression areas are often rich with pinch-out structural type where promising oil traps could be found. An understanding of how the depth of the basin changes from region to region is therefore important. In Iraq, many areas lack to considerable 3D seismic surveys due to bad quality seismic data, Abdulrahim and Al-Rahim (2019). One of these locations is Al-Ma'aniyah area, where the $2 \mathrm{D}$ seismic sections need to an extensive work for corrections to reflect the subsurface

DOI: 10.46717/igj.54.2D.9Ms-2021-10-28 
image. Therefore; Al-Ma'aniyah depression area is announced for foreign investment for that reason and others. Regarding previous studies, Al-Ma'aniyah depression was studied by Al-Rahim and Lima (2016) applied the absolute second horizontal gradient of the gravity field to interpret the source origin of Ma'aniyah depression; their results support a basin source of the depression that has a negative anomaly of -18 mGal., Abdulrahim and Al-Rahim (2019) studied Al-Ma'aniyah area utilizing the magnetic data. They interpreted the magnetic sources (their depths and distribution) using $3 \mathrm{D}$ forward and inverse modeling. The interpreted depths were 7-8 $\mathrm{km}$ at north and northeastern part of studied area and about 8-10 km at south and southwestern parts. depicts the main result of their study where all of prismatic source bodies are surrounding a main central and north-south extending depression. The figure also shows that the bodies oriented nearly east-west may explain the truncation of Al-Ma'aniyah depression at the north as mentioned earlier. Accordingly, the aim of this study is to analysis the Bouguer gravity data of the area which could help in giving information about basement depth and relief beside determination of locale anomalies to be at the first priority to revive the extensive seismic exploration work. Al-Ma'aniyah depression area is located at the southwestern part of Iraq. The study area is relatively of a flat topography, slopping gently towards E and NE. An elevated part (300-400 m, a.s.1.) exists along with the Iraqi-Saudi Arabia border (Ansab-Ma'aniyah), while the northeastern part (20-150 m, a.s.1.) is along the Euphrates River (Ma'ala, 2009) (Fig. 1).

\section{Geology and Tectonic Setting}

Al-Ma'aniyah depression which lies above the Nukhaib Graben is over $100 \mathrm{~km}$ long and $20 \mathrm{~km}$ wide. Paleocene rocks are exposed on both sides of the depression; Middle Eocene limestone occurs in isolated outcrops protruding through of gravel (Fig. 2).

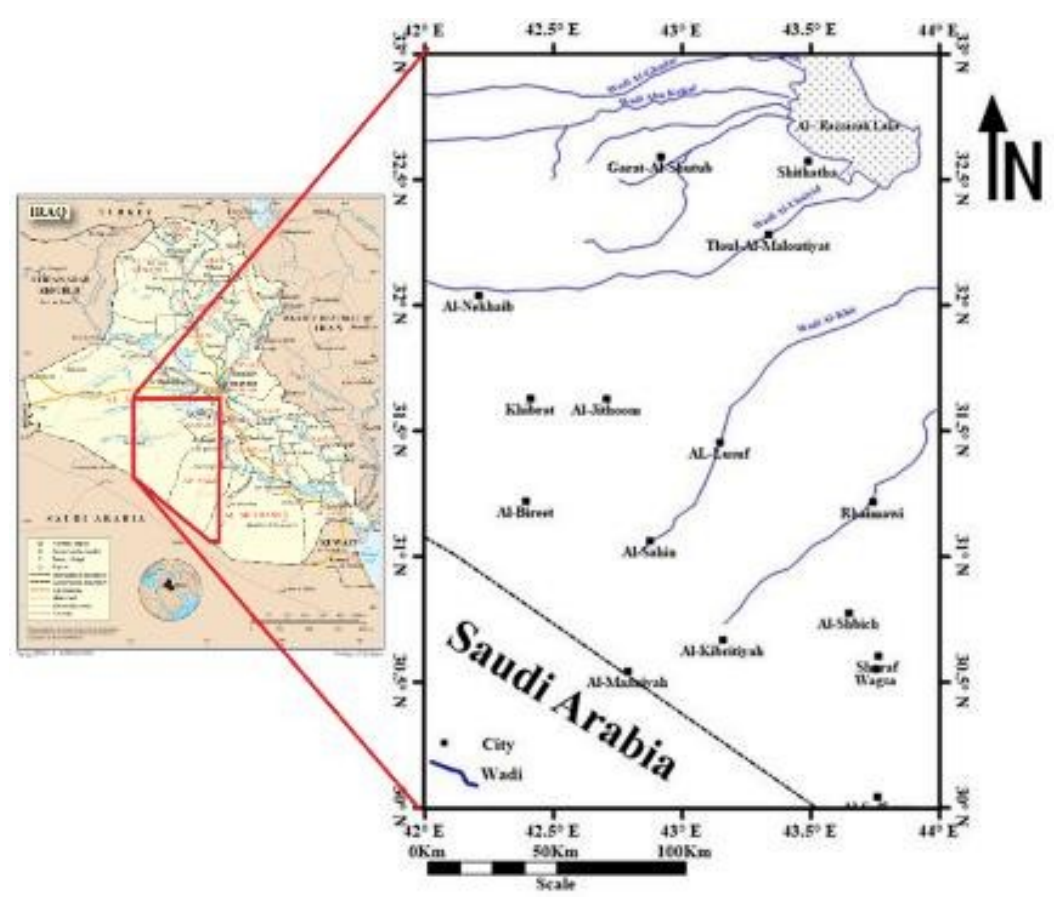

Fig. 1. Location and base map of the study area, (modified after NationMaster-Maps of Iraq, 1996). Most of wadies in this area have a NE trend toward the Mesopotamia and Al-Razzah Lake

The Umm Er Radhuma Formation is the oldest exposed rocks in the study area. The youngest rocks are of Pliocene-Pleistocene age such as Zahra Formation, (Sissakian \& Fouad, 2015). Tectonically, Al-Ma'aniya depression area is located in the stable shelf, within Rutba-Jezira Zone and Salman Zone. Tectonic map (Fig. 3) shows that the general trend of transversal fault systems is NE-SW direction. The 
transversal fault systems formed during Latest Precambrian as a result of Nabitah Orogeny and they reactivated repeatedly during the Phanerozoic (Jassim and Goff, 2006). The E-W compressional stress during the early Permian in syn- Hercynian subcrop, created N-S trending uniforms between deposits of fluvioglacial and Aeolian sediments. These uniforms are evidence to the lower Paleozoic sequence, which is probably the Precambrian basement sub crop even in the Hercynian unconformity (Jassim and Goff, 2006). The relatively thin Phanerozoic sediments cover the Precambrian NW-SE and NE- SW fractured continental basement complex (Ma'ala, 2009).

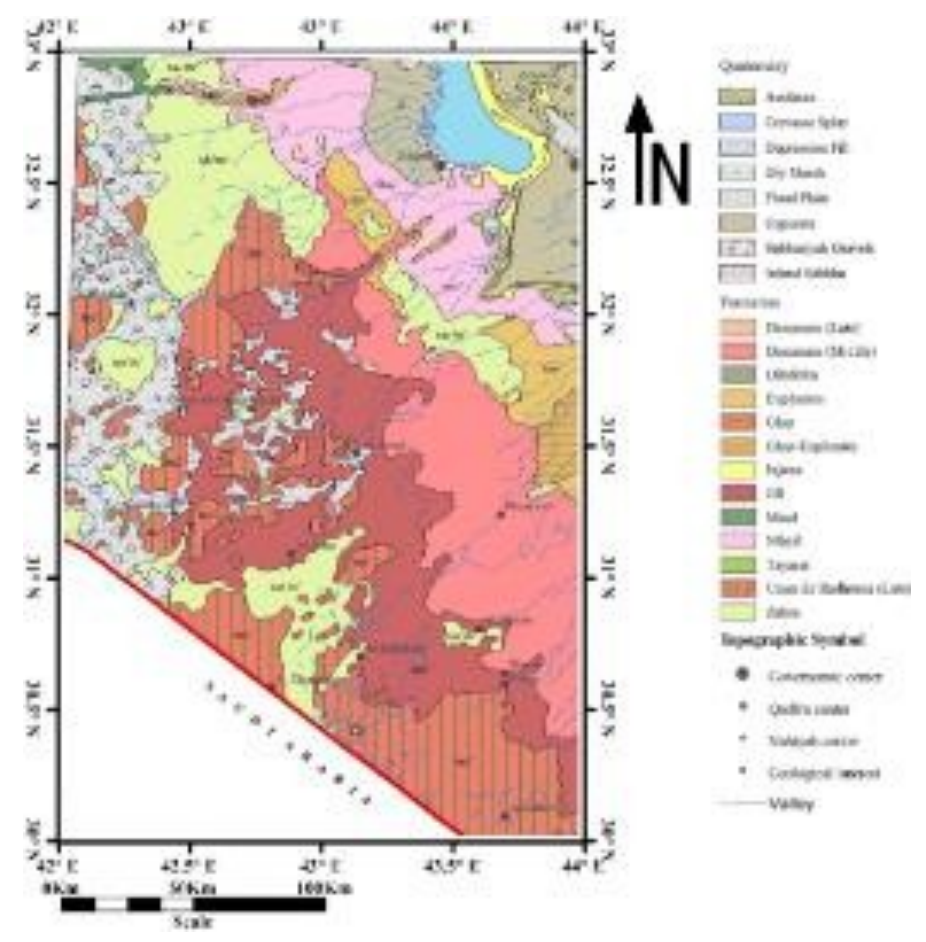

Fig. 2. Geological map of the study area (modified after Sissakian \& Fouad, 2015)

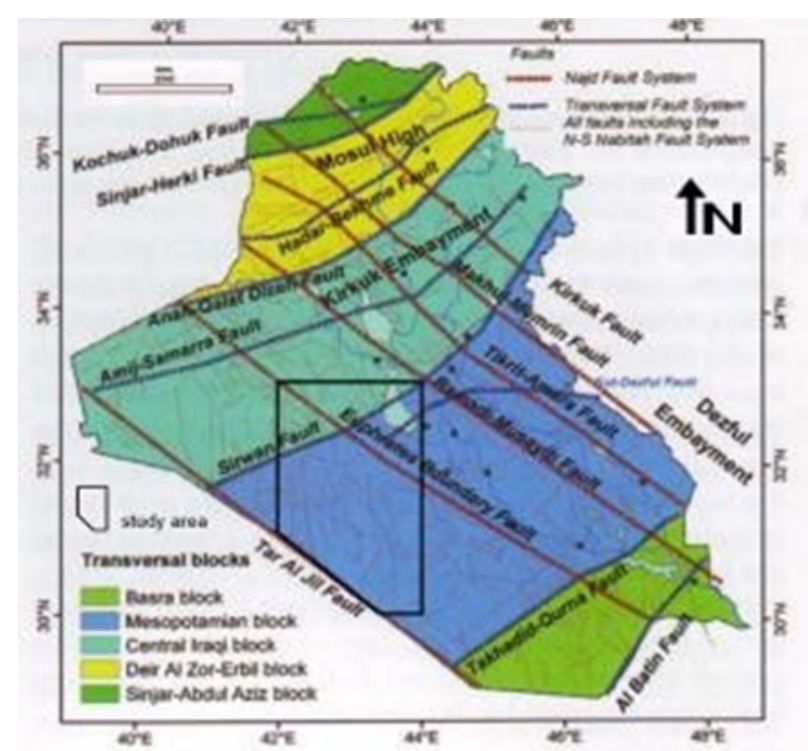

Fig. 3. Location of Al-Ma'aniya depression area within the transversal blocks and fault systems of Iraq (Jassim and Goff, 2006) 


\section{Materials and Methods}

\subsection{Boundary Determination and Previous Study for Al-Ma'aniyah Area}

Fig. 4A shows Free-Air Anomalies (FAA) derived from satellite altimetry for the Middle East and surrounding area (Sandwell et al., 2014). On the land; these Free-Air gravity anomalies comes from EGM2008 and on the ocean they come from radar altimetry. A Huge Basin (HB) includes and covers the Mesopotamia, the Arabian Gulf and the eastern part for most of Saudi Arabia territory. To the west of HB; a north-south extending depression feature (The yellow-colored area in A map) is located and delineates the area of interest in this study. Fig. 4B is a zoom for the northern part of this depression.

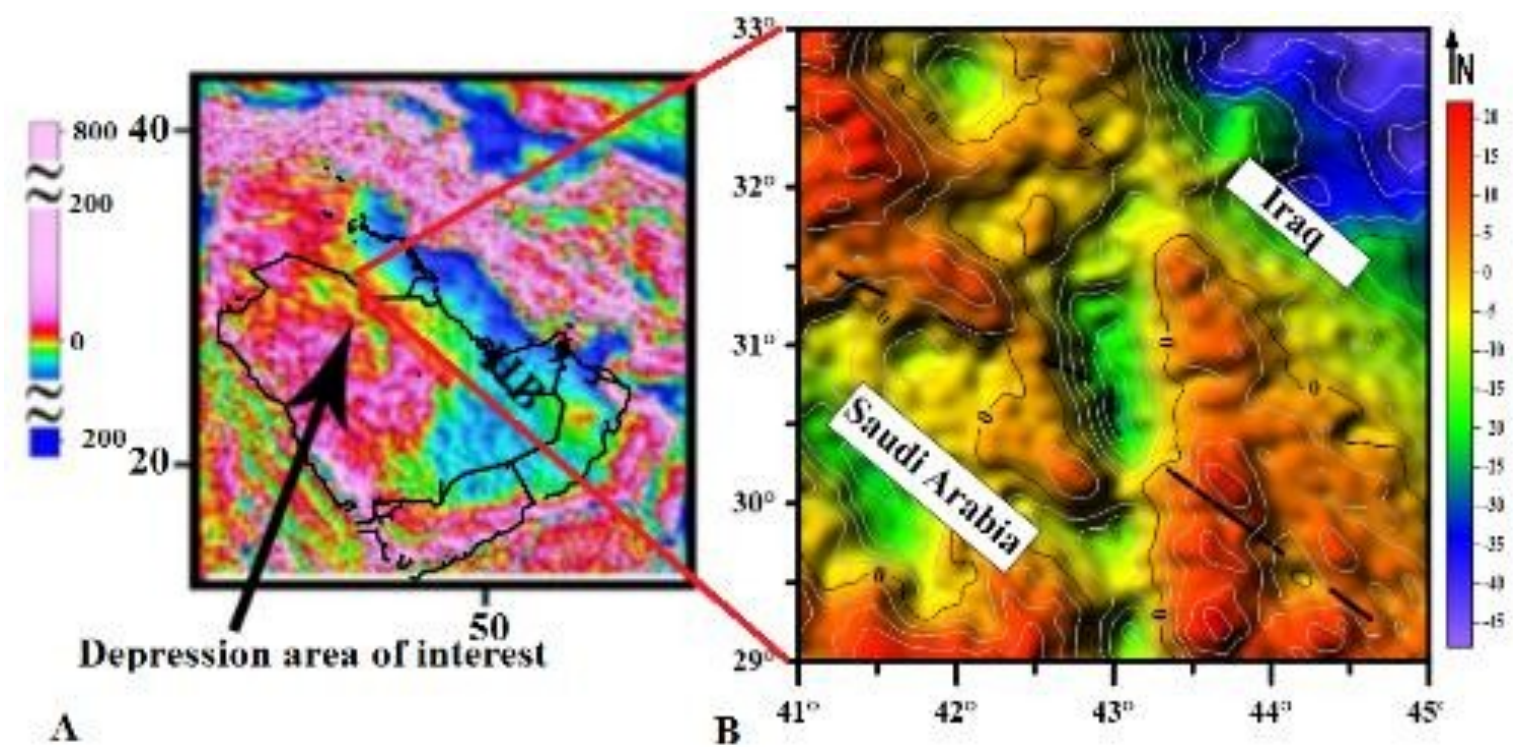

Fig. 4. A) Free-Air Anomalies (FAA) derived from satellite altimetry for the Middle East and surrounding (Sandwell et al., 2014); B) A zoom for northern part of the NS extended depression

For edges detection of this part of the depression which named Al-Ma'aniyah depression in the Iraqi territory part of this study area (Fig. 5A), a Total Horizontal Derivative (THD) operator is applied on the FAA data which are firstly smoothing (Fig. 5B) to enhance the result (Fig. 5C). Clearly, the Al-Ma'aniyah depression (the area outlined by the white polygon in Fig. 5C) has a N-S extend with some extra width at its northern part where this extend is suddenly interrupted (Fig. 6).

\subsection{Gravity Data}

The gravity data of the study area (Fig. 7) are provided from total Bouguer map of Iraq. Bouguer gravity map of Iraq was reproduced using $1 \mathrm{~km}$ cell size with minimum curvature method for gridding the raw data (Kaxia et al., 2011).

\subsubsection{Spectral Analysis as a Tool for Regional-Residual Separation}

In power spectrum method, a low pass filter is applied to Bouguer gravity data to calculate the regional field and high pass filter to get the residual. The cut-off wavelength used is $60 \mathrm{~km}$ to obtain the regional and residual fields. 


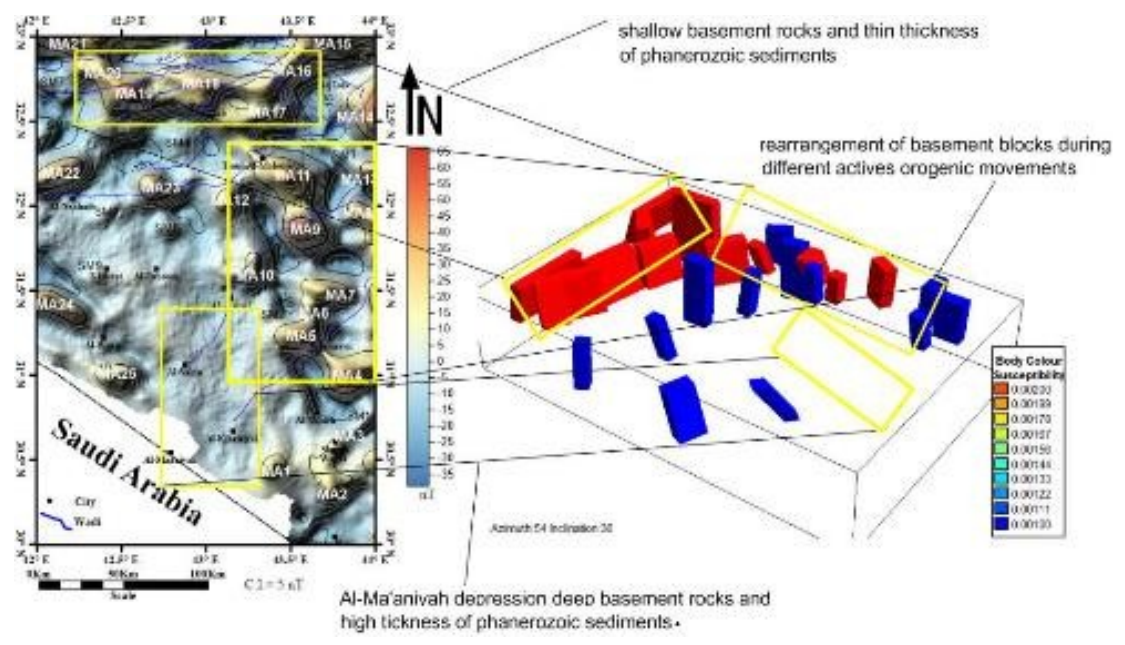

Fig. 6. Main results of studying Al-Ma'aniyah area using a 3D modeling and inversion of the magnetic data (after Abdulrahim and Al-Rahim, 2019)

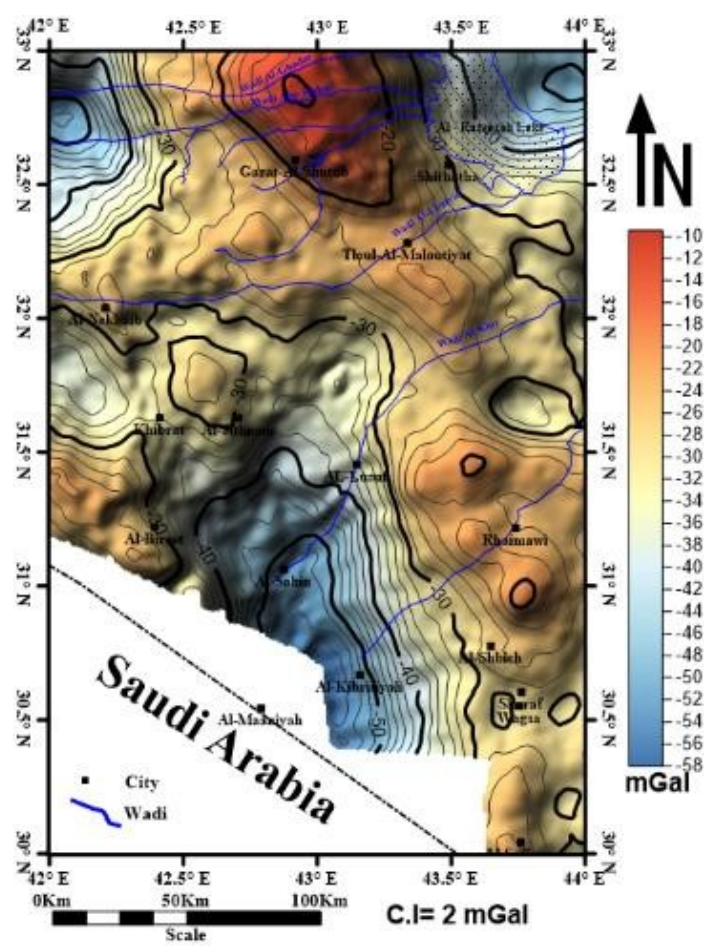

Fig. 7. Bouguer gravity map for the study area

The regional map (Fig. 8A) shows low gravity values enclosed by high values that confirm the depression feature. The interpreted residual gravity map of study area (Fig. 8B) shows main positive gravity anomalies associated with shallow basement of high density rocks marked as GA. The positive gravity anomalies in eastern direction marked by GA1, GA2, GA3, GA4, GA5, GA6 and GA7 at Rhaimawi city were interpreted as high relief structures resulted in uplifted basement rocks eastwards. The main positive anomalies in north marked by GA11, GA12, and GA13 and GA14 at Garat-Al-Shutub city could be correlated with shallow depth and high density basement rocks. The anomaly GA11 is divided to many small anomalies. Wadi Abu-kuhaf runs between anomalies GA11 and GA12 that suggest a strike slip fault. The anomalies marked by GA15, GA16, GA17, GA20, GA21 and GA22 in the western part of the map could be related to shallow basement rocks. The anomalies marked by GA23, GA24, GA25, GA26, GA27, GA28, GA29 and GA30 in the southwest at A1-Breet 
may also related to shallow basement rocks within Al-Ma'aniyah depression. All these anomalies are basement related with different relief that will be interpreted latter in the quantitative analysis. These positive anomalies are well coincided with prismatic bodies which have been previously interpreted in the magnetic data, after Abdulrahim and Al-Rahim, 2019 (Fig. 6). The most important thing is that, this basement high may affect the overlain sedimentary cover and make some type of folding structures, which what we are usually looking for in oil exploration.

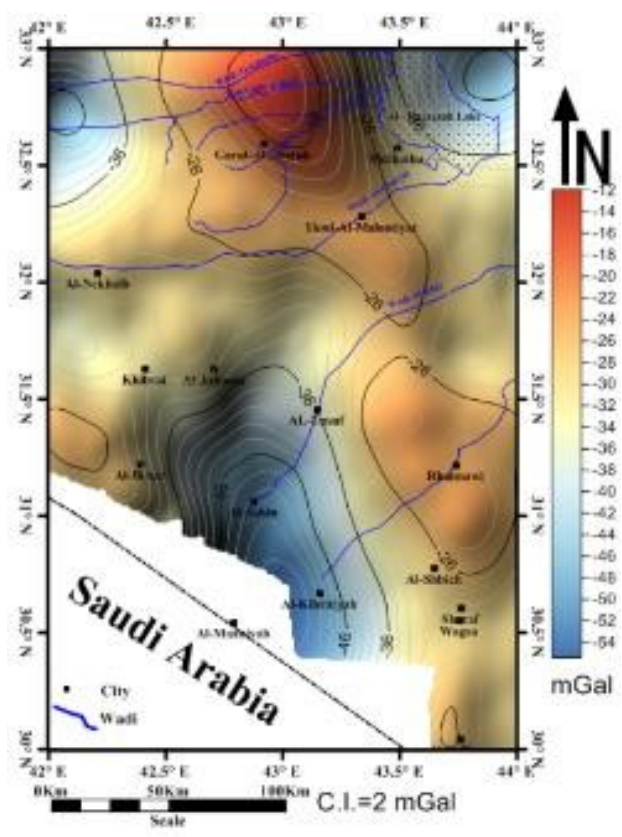

A

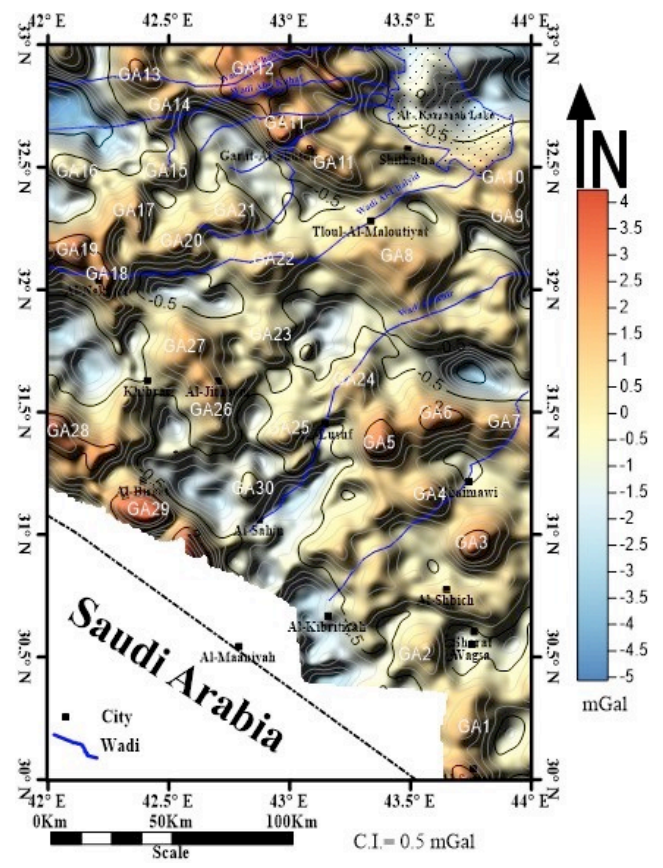

B

Fig. 8. A) Regional map created using the power spectrum method, a low pass filter with wavelength cut-off $60 \mathrm{~km}$ is used; B) The residual map created by using a high pass filter with wavelength cut-off $60 \mathrm{~km}$. Positive anomalies marked by GA1 to GA30 are shown

\subsubsection{Edge Detection Techniques}

\section{- Total Horizontal Derivative (THD)}

THD is a boundary detection method. THD was applied to determine edges of the gravity sources in study area. Al-Rahim (2017) applies the THD method to synthetic models with and without regional trend. He showed that the regional trend effects on the result of THD analysis. Fig. 9A and B show the resultant THD maps after applying the method on the Bouguer anomaly grid and the residual grid (Fig. 8 ) respectively. It is obvious that the boundaries of each anomaly are enhanced.

\section{- First Vertical Derivative (FVD)}

The FVD is a good method for resolving anomalies over individual structures and importantly suppresses the regional content of the data. The FVD sharpens the gravity structures and some anomalies are deviated into two or three parts using FDV method. The applied FDV method is used for enhancement and sharpening up anomalies over bodies and it tends to reduce the anomaly complexity, allowing clearer imaging of the causative structures. The transformation can be noisy since it will amplify short wavelength and noise, $(\mathrm{GETCH}, 2007)$. First vertical derivative is applied to Bouguer 
gravity data for the study area to delineate and enhance the amplitude of the anomalies (Fig. 10). All of the interpreted anomalies are confirmed and some are branched to more than one features. Definitely, the noise would be enhanced too and apply smoothing to first vertical derivative data is need to obtain better result
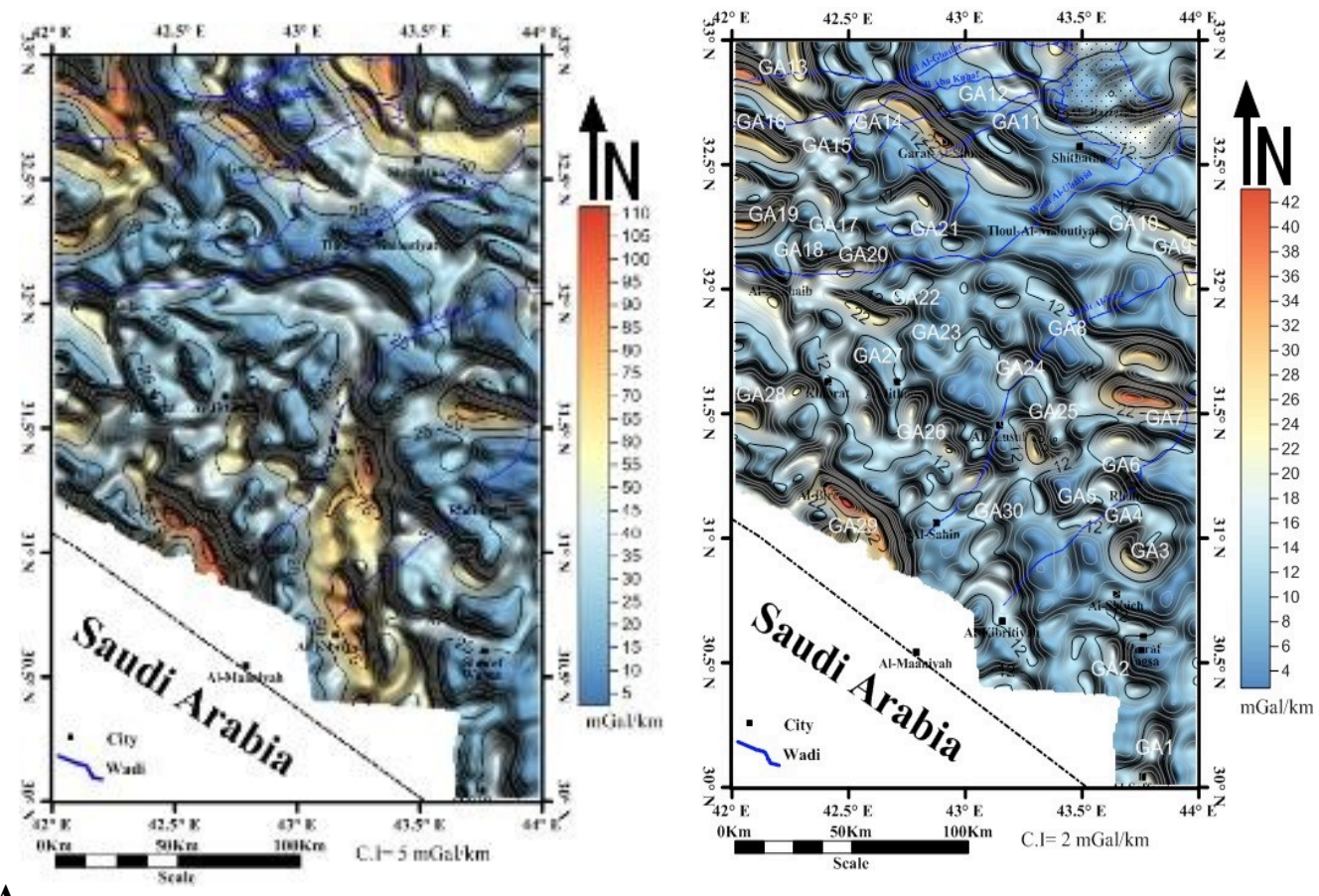

A

B

Fig.9.Total horizontal derivative of A) Bouguer gravity map and B) residual anomalies. The boundaries of the anomalies are enhanced in (B) as a result of removing the regional effect.

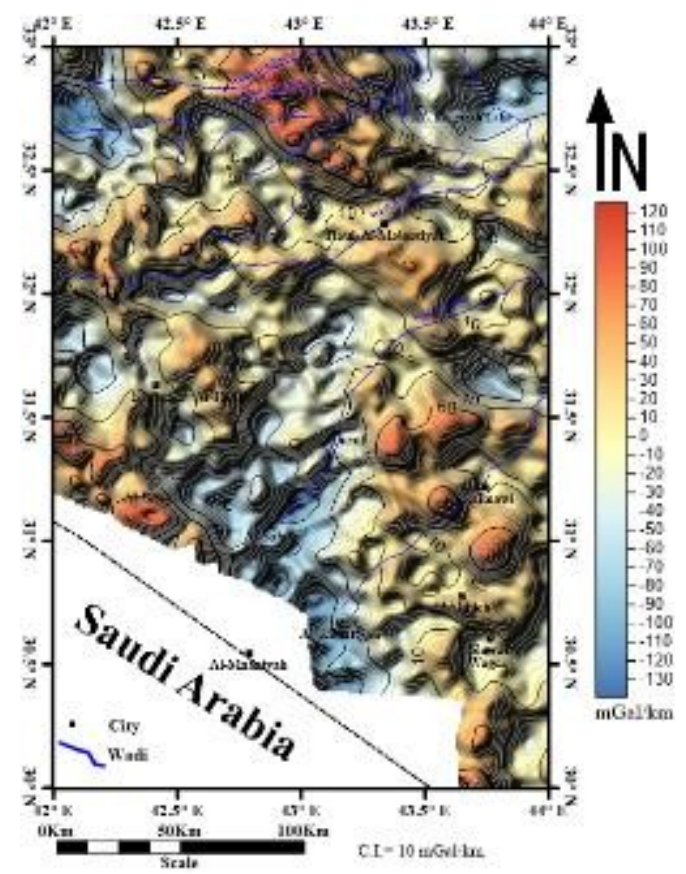

Fig. 10. Smoothed first vertical derivative map of Bouguer gravity shows residual anomalies in the study area 


\subsubsection{Depth Estimates by 2.5D Forward Modeling and 3D Views}

Encom ModelVisionTM v12.0 software is used in modeling and inversion of gravity data. Bougure gravity map is convert to stacked profiles map as shown in Fig. 11. Nineteen profiles (named L1 to L19) are taken to 2.5D gravity field model of the gravity field of the study area. Matching processing of all modeled lines are assumed by polygons represented the sedimentary cover, changes in dimensions and depths of these polygons are done during the matching processing. Fig. 12 shows the modeling polygons and bodies to estimate the observed Bouguer gravity data. To get more clear figures about the modeled bodies, a 3D perspective presentation for the subsurface modeled structures of the gravity data is shown in Figs. 13 and 14 with the different directions.

\section{Results and Discussions}

The density chosen to the sedimentary cover in gravity model is $\mathrm{D}=2.55 \mathrm{~g} / \mathrm{cm} 3$. This value gives good matching between gravity data and model line and gives a reasonable interpretation for the subsurface structure. The L1 profile (Fig.12) shows a depth about $5 \mathrm{~km}$ in the central part with high density mass $(\mathrm{D}=2.77 \mathrm{~g} / \mathrm{cm} 3)$ to get a best fitting with the positive gravity and an assumed low density in the western part of the profile $(\mathrm{D}=2.0 \mathrm{~g} / \mathrm{cm} 3)$ to match the negative gravity. The L1 agrees with quantitative interpretation for magnetic data shown in Fig. 6. The L2 profile has the same pattern of L1 profile so as L3 profile. In L4 profile, the sedimentary cover with density ( $\mathrm{D}=2.55 \mathrm{~g} / \mathrm{cm} 3)$ is enough to get the best fit with the observed gravity data and shallow depth in the central part of the profile.

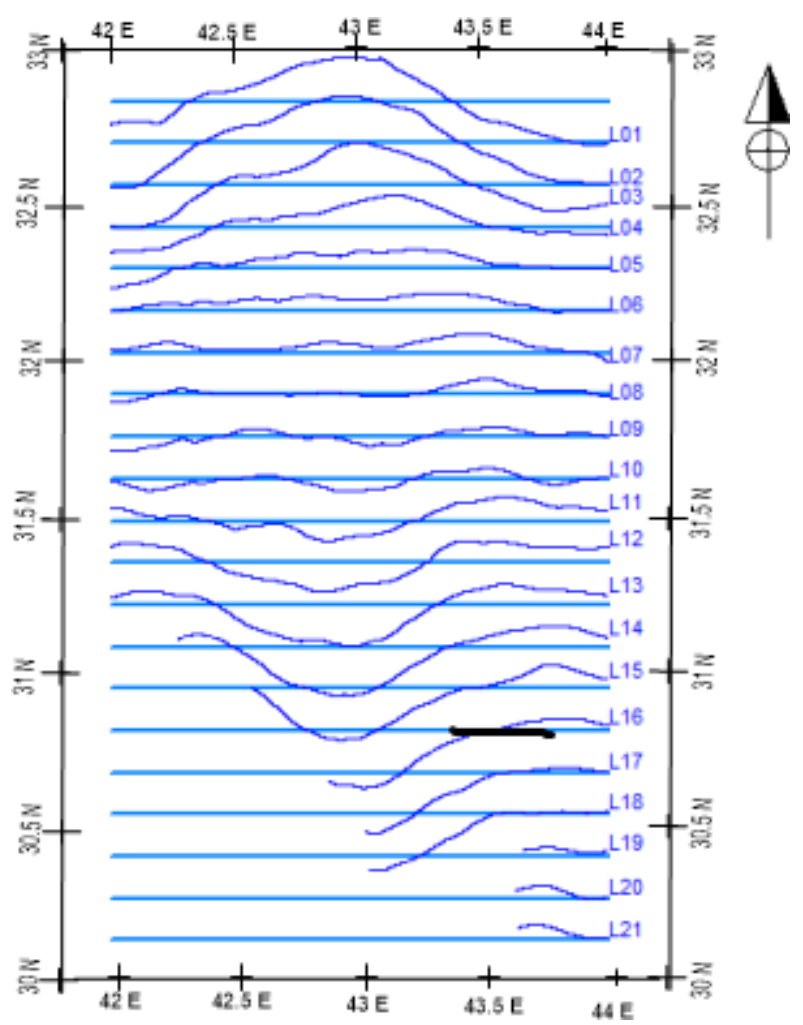

Fig.11. Nineteenth stacked profile across the Bouguer map. These profiles named from L1 to L19 are used for model the gravity data

The L5, L6, L7 and L8 profiles (Fig. 12) show a basement relief at different depths. All profiles in this figure have good matching with the observed gravity data. Modeling the gravity field for L9, L10, L11 and L12 profiles are also shown in Fig. 12. The central parts of these profiles have more depth than the external part and the location of Al-Ma'aniyah depression is observed. Profile L12 needs to include a 
low-density body $(\mathrm{D}=2.2 \mathrm{~g} / \mathrm{cm} 3)$ to compensate the low values in the observed gravity data. This low-density body my represent a salt body or metamorphic rock (Quartzite) body. The same habitats are for modeling the gravity field for L13, L14, L15 and L16 profiles as shown in Fig. 12 which represents the southern part of Al-Ma'aniyah depression. Also, Fig. 12 shows the results of modeling the gravity field for L17, L18 and L19 where the profiles are shortening as the end of study area. The 2.5 D models of gravity data have very good agreements with qualitative interpretation of gravity data from the high positive gravity anomalies in north direction and negative anomalies in south and south west direction of the study area. In addition, the 2.5D models of the gravity agree with qualitative interpretation of gravity data by the basement rocks uplift in east and north directions and the basement rocks subsidence in the south and southwest directions at Al-Ma'aniyah depression.

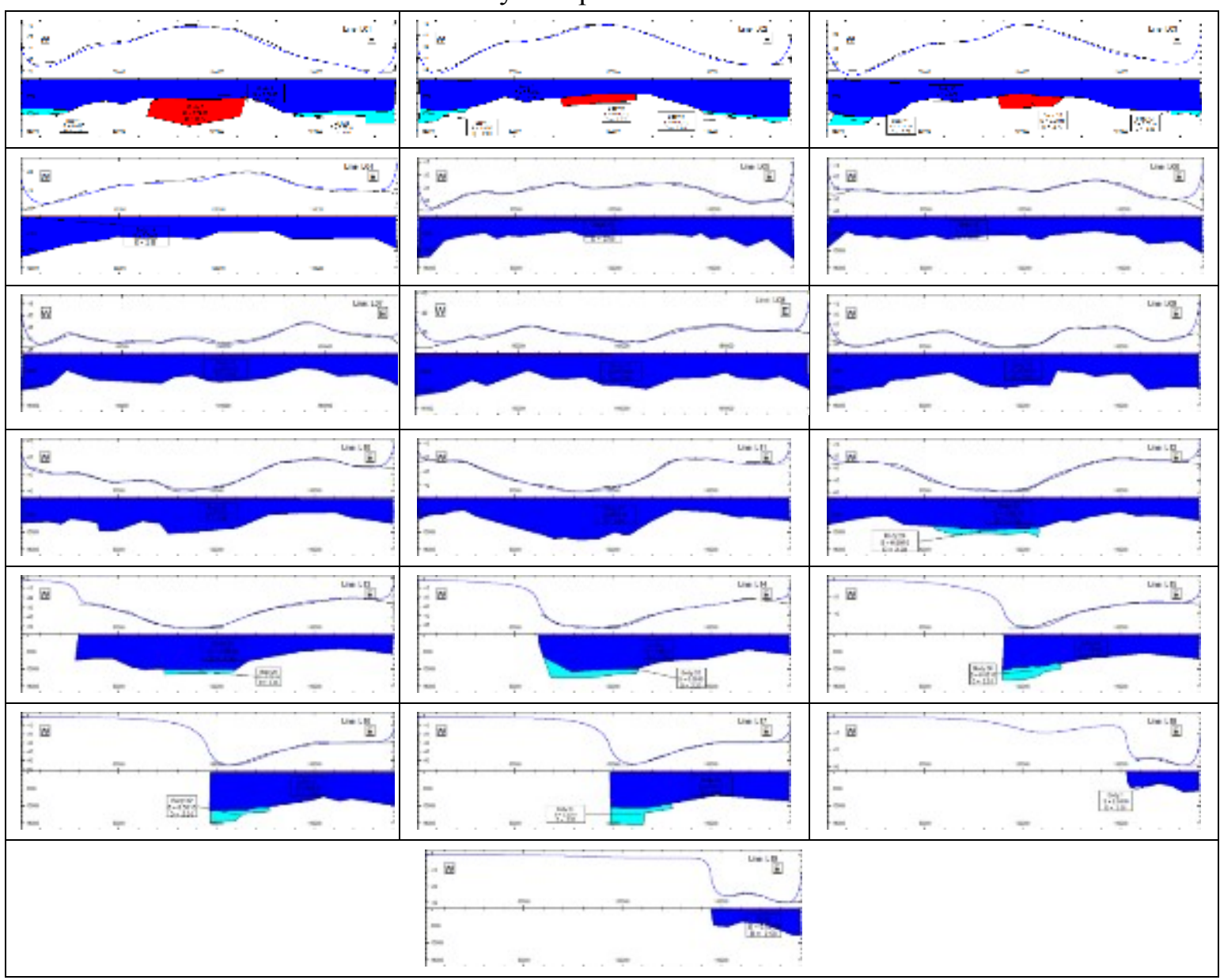

Fig. 12. 2.5 D modeling of the nineteenth gravity profiles. Profile L1 (upper left corner) to profile L19 (at the bottom)

The 3D subsurface view derived from gravity data for the study area shows many structures and features in the subsurface (Fig. 13). The 3D view shows the deep basement rocks in south and southwest direction of study area and uplift basement rocks in north direction of study area. Also, the 3D view shows the negative anomalies in south and southwest direction of the study area, which related to the subsidence of basement rocks in this region and coincide with low density rocks such as felsic rocks. The 3D subsurface view (Fig. 14 A and B) for study area reflect the Bouguer map from the high positive gravity anomalies in the north related with shallow basement rocks and low negative gravity anomalies in south and southwest direction related to subsidence in basement rocks. The negative anomalies of Al-Ma'aniyah depression could be correlated with a subsidence in basement rocks at a depth of $10 \mathrm{~km}$. The negative anomalies in Bouguer map in northeast and northwest could be in accordance with a 
subsidence in the basement rocks in that directions. Basement depth map can be considered as important tools in deducing the structures and stratigraphic features existing in the sedimentary sections overlying basement rocks. From the relief of the base of polygons in the nineteenth $2.5 \mathrm{D}$ modeled gravity profiles (Fig 11), a basement relief map is extracted as shown in (Fig. 15). The depth of the basement map for the study area (Fig. 15) shows shallow basement in the northern and northwest part of the study area with a depth value of about 5 to $7.5 \mathrm{~km}$. Deep basement depth in the southern and southwest part of the study area (to about 7.5 to $10 \mathrm{~km}$ ) coincides with Al-Ma'aniya depression area. The positive gravity anomalies in east are possibly related to a shallow basement depth of about $5 \mathrm{~km}$.

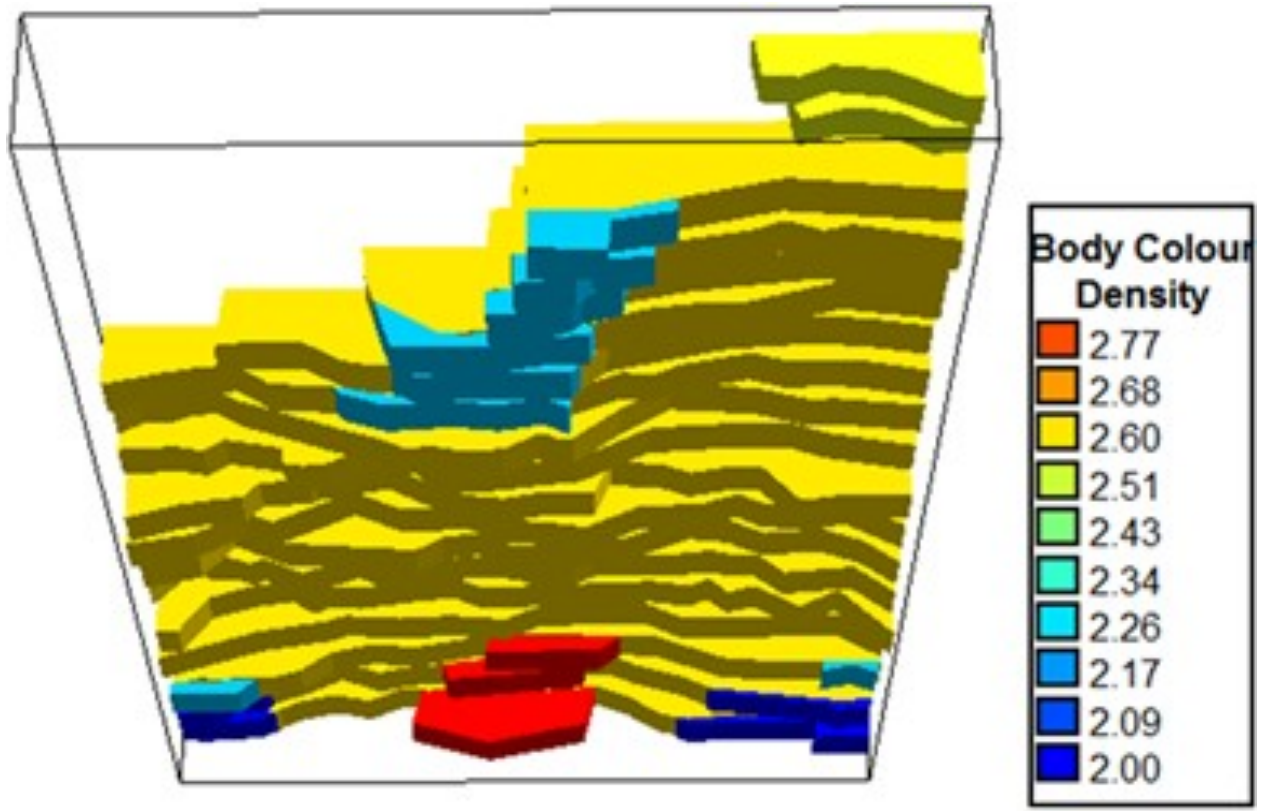

Azimuth: 359 Inclination:-28

Fig.13. A 3D perspective down-up view for the subsurface modeled structures in the study area using inversion of gravity data

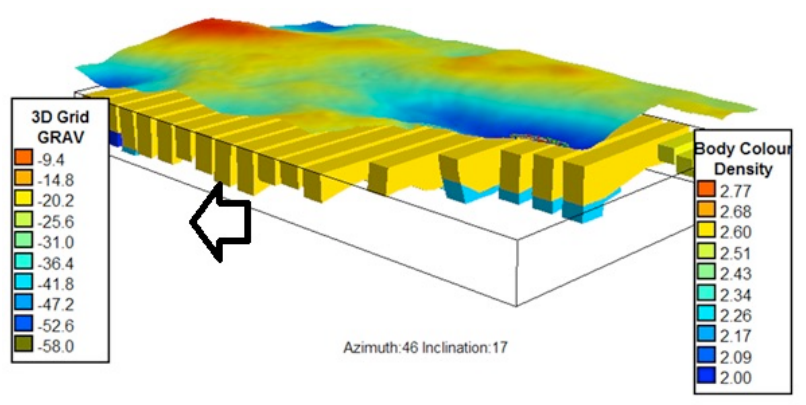

A

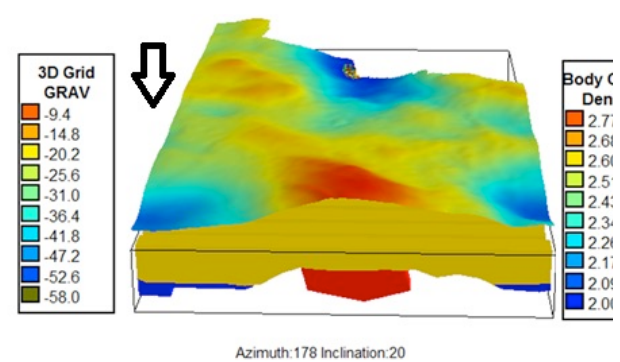

B

Fig. 14. A) Rotated 3D prospective up-down view NW direction for thesubsurface-modeled structures. B) Rotated 3D prospective up-down view SN direction for the subsurface-modeled structures with Bouguer anomaly map (superimposed) of the study area for each figure. 


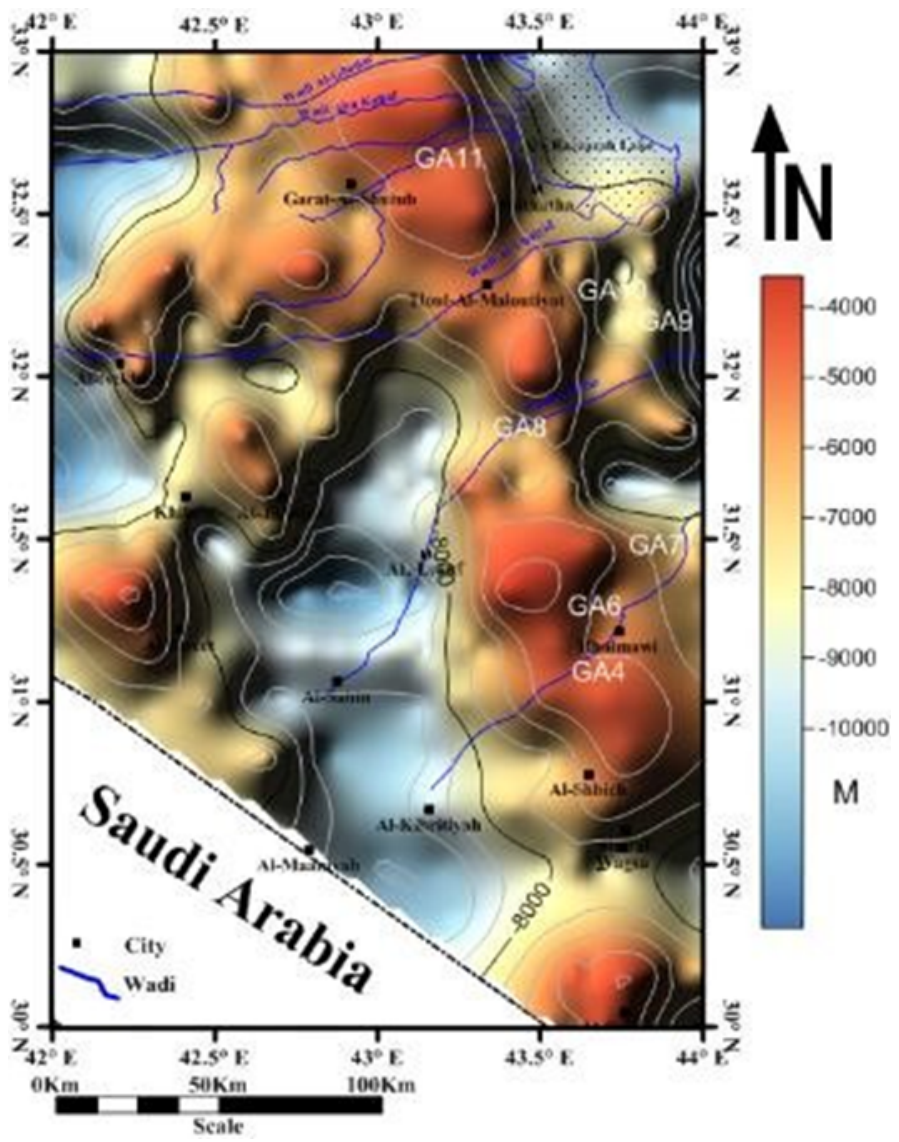

Fig. 15. Depths to basement map in study area extracted from 2D modeling of gravity data

\section{Conclusions}

Quantitative analysis for the gravity data in Al-Ma'aniyah depression using nineteen 2.5D forward modeled profiles and inverse modeling reveals an uplift in basement rocks in north and subsidence to the south of the study area. A 3D viewing shows a clear image for the basement relief, uplift and subsidence locations. A positive density body (mafic body) is needed to be located at the base of the basement in the northern part of the study area to compensate the positive gravity data beside a shallow basement depth. Whilst, a negative density body is located in the depression to add an extra negative value to the model of Al-Ma'aniyah depression that is beside deep depths for the basement. The interpretation for this negative density body in the depression area may be related to Infracambrian salt structures (this is coinciding with the interpretation of Jassim and Goff (2006) or Quartzite metamorphic rock (that is metamorphosed from the Infracambrian sand in the deep successions). The Purj Formation is delineated as a very good refractor above the basement in different locations in the western Iraqi desert and maybe encountered also in the study area. The depth of basement rock in the south of Al-Ma'aniyah depression ranges from 7.5 to $10 \mathrm{~km}$ with changes in relief in the depression location. A basement map for the study area is extracted using the integrated profiles of the $2.5 \mathrm{D}$ modeling method. The presented basement map shows that the basement depth in the northern part ranges from 5 to $7.5 \mathrm{~km}$ at Garat-Al-shutub region.

\section{Acknowledgements}

The authors are very grateful to the Editor in Chief Prof. Dr. Salih M. Awadh, the Secretary of Journal Mr. Samir R. Hijab. and the Technical Editors for their great efforts and valuable comments. 


\section{References}

Abdulrahim, H., \& Al-Rahim, A. M. 2019. Determinations of the depths to magnetic sources over Al-Ma' aniyah Depression area-southwest Iraq Using the aeromagnetic data and their tectonic implication. Iraqi Journal of Science, 60(1), 91-102.

AL-Rahim, A. M., \& Lima, W. A. 2016. Basin or intrusion, a new method to resolve non- uniqueness in gravity interpretation. Iraqi Journal of Science, 57(1B), 480-491.

Al-Rahim, A. M. 2017. Enhance the delineation of masked structures in southern Iraq by applied the Biharmonic operator to their gravity field. Baghdad, Iraq: Iraqi Journal of sciences, 58(1A), 79-87.

Ali, M. Y., Watts, A. B., Farid, A., 2014. Gravity anomalies of the United Arab Emirates: implications for basement structures and infra-Cambrian salt distribution. GeoArabia, 19(1):85-112

Jassim, S. Z., \& Goff, J. C. 2006. Geology of Iraq. Dolin, Hlavni 2732, Prague and Moravian Museum, Zelnytrh 6, Brno, Czech Republic.

Kaxia, L., Derek F., Tom K., and Al-Bassam, K., 2011. Reprocessing of Iraq magnetic and gravity data. The Society of Exploration Geophysicists and the Chinese Geophysical Society GEM Beijing 2011: International Workshop on Gravity, Electrical \& Magnetic Methods and Their Applications Beijing, China, $10-13$.

Ma'ala, K. A., 2009. Tectonic and structures evolution: Geology of Iraq southern desert. Iraqi Bull. Geol.Min. 2, 35-52.

Rao, C. V., Pramanik, A. G., Kuma, R., Raju, M. L.,1994. Gravity interpretation of sedimentary basins with hyperbolic density contrast. Geophysical Prospecting, 42, 825-839

Sandwell, D. T., Muller, R. D., Smith, W. F., Garcia, E., \& Francis, R., 2014. New global marine gravity model from cryosat-2 and Jason-1 reveal buried Tectonic Structure. Science, 346(6205), 65-6.

Sissakian, V. K., \& Fouad, S. F., 2015. Geological map of Iraq, scale 1: 1000 000, 2012. Iraqi Bulletin of Geology and Mining, 11(1), 9-16. 